\title{
Reproduction of Esthetic Individuality in Upper Immediate Complete Denture
}

\author{
Reproducción de la Individualidad Estética en Prótesis Completa Inmediata Superior
}

\begin{abstract}
Eliana de Souza Bastos Mazuqueli Pereira1; Fernando Accetturi²; Rachel Gomes Eleutério'; Daniela Vieira Buchaim ${ }^{1,3}$; Rogério Leone Buchaim ${ }^{1,4} \&$ Juliana Trindade Clemente-Napimoga ${ }^{5}$
\end{abstract}

PEREIRA, E. S. B. M.; ACCETTURI, F.; ELEUTÉRIO, R. G.; BUCHAIM, D. V.; BUCHAIM, R. L. \& CLEMENTE-NAPIMOGA, J. T. Reproduction of esthetic individuality in upper immediate complete denture. Int. J. Odontostomat., 14(4):648-652, 2020.

ABSTRACT: Prosthodontics, in general, aims to rehabilitate the masticatory function of the patient, as well as the stomatognathic system, maintaining his or her individual facial characteristics. The immediate removable complete denture is placed immediately after extraction of the natural teeth and allows adaptation of the patient from the dentate state to the denture, until the definitive denture is placed. When an immediate complete denture is fabricated, esthetics plays a fundamental role and thus the assembly of artificial teeth can be performed maintaining the same position, alignment and arrangement of the remaining anterior teeth, providing a natural and esthetic appearance to the denture, thus the transition from the dentate to the edentulous state is less noticeable. This paper reports the case of a patient who needed oral rehabilitation with an immediate upper complete denture and presented favorable smile esthetics of the anterior teeth, which allowed the preservation of alignment, position and arrangement of natural teeth during the assembly of artificial teeth, maintaining and preserving the esthetic individuality and facial harmonization, meeting the patient's desire and expectations.

KEY WORDS: aesthetic, immediate, artificial teeth, dentures.

\section{INTRODUCTION}

The personality of an individual is expressed by the usual way of being and conduct, in which personality is strongly influenced by the appearance of teeth. Thus, dental professionals search for a better arrangement of artificial teeth to encourage the development of personality attractions; complete dentures can and should restore this natural appearance whenever possible.

Complete dentures, either immediate or mediate, are tissue-supported devices that aim to fully reestablish the stomatognathic system. The immediate denture is fabricated before extraction of the patient's natural teeth, especially anterior teeth (Meleti et al., 2002; Caputi et al., 2013). Its main difference is related to the basal area, fibromucosa and bone tissue, when the denture fabrication is initiated. In immediate dentures, there is a combination of surgical acts procedures concomitantly with denture fabrication, thus the extraction of remaining teeth and occasional procedures for bone regularization are performed in the same clinical session as denture placement.

The immediate complete denture has been performed for a long time, yet this type of denture was not often performed in dentistry, either because the professionals did not give proper value to this type of denture, or because the esthetic requirement mightbe lower than currently (Bastos \& Rodrigues, 2015). Rehabilitations with tissue-supported complete dentures are still widely used, although the number of tooth extractions is decreasing over the years. Also, recently, the digital technology (CAD-CAM) has been used in the fabrication of complete dentures,

\footnotetext{
${ }^{1}$ School of Dentistry, University of Marília (UNIMAR), Marília 17525-902, Brazil.

${ }^{2}$ Private Dental Clinic, Fernando Accetturi Implants and Aesthetic Dentistry, Marília, 17525-170, Brazil.

${ }^{3}$ Medical School, University Center of Adamantina (UniFAI), Adamantina 17800-000, Brazil.

${ }^{4}$ Bauru School of Dentistry, University of São Paulo (FOB/USP), Bauru 17012-901, Brazil.

${ }^{5}$ School of Dentistry, São Leopoldo Mandic (SLMANDIC), Campinas 13045-755, Brazil.
} 
considerably reducing the time required for denture fabrication (Venezia \& D'Amato, 2017; Neumeier \& Neumeier, 2016; Fang et al., 2018).

The immediate complete denture aids to reestablish the esthetics, comfort, social life and function of the patient. It is well indicated for patients who need extraction of several teeth and thus do not accept the edentulous situation for some time after extraction due to the need of surgery healing (Bastos \& Rodrigues). The transition from dentate to edentulous condition is the main factor for the indication of immediate complete dentures, especially considering the social aspects (Santos et al., 2015), also offering favorable functional and esthetic conditions, providing temporary support of a dentate individual until a definitive denture may be fabricated (Torcato et al., 2012; Tadi et al., 2013).

The complete denture can also be used as a temporary denture in patients undergoing implant surgery, before fabrication of definitive dentures, either overdenture or protocol (Afshari et al., 2012). According to Torcato et al., immediate complete dentures represent a necessary, proven, advantageous and effective clinical procedure for patients who will inevitably lose their fully or partly dentate condition, despite being a slightly more expensive approach that requires more sessions for post-placement control than conventional complete dentures. Thus, patients in need of complete dentures should receive reestablishment not only of tooth function (mastication, speech and lip support), but also of esthetics.

The selection of teeth and their assembly influence the facial harmony and esthetics and may alter the facial appearance. Thus, planning must be very careful and, for the assembly of artificial teeth, three clinical situations may be observed: 1) the remaining teeth present natural and esthetic position, alignment and disposition (which may be reproduced in denture fabrication); 2) there is need for corrective surgery and establishment of a new position, alignment and arrangement of artificial teeth; 3 ) the remaining teeth, when present, exbibit precarious poor that, in combination, provide poor esthetics, requiring corrections subjected to the esthetic analysis of the attending professional. The dental professional should make all efforts to restore the shape and function of the stomatognathic system and try to provide the most natural and comfortable appearance as possible to the patient (Trentin et al., 2016). Thus, this case report aims to present the fabrication of an immediate upper complete denture with assembly of artificial anterior teeth in the same position and alignment of the remaining teeth, to reproduce the same natural smile esthetics.
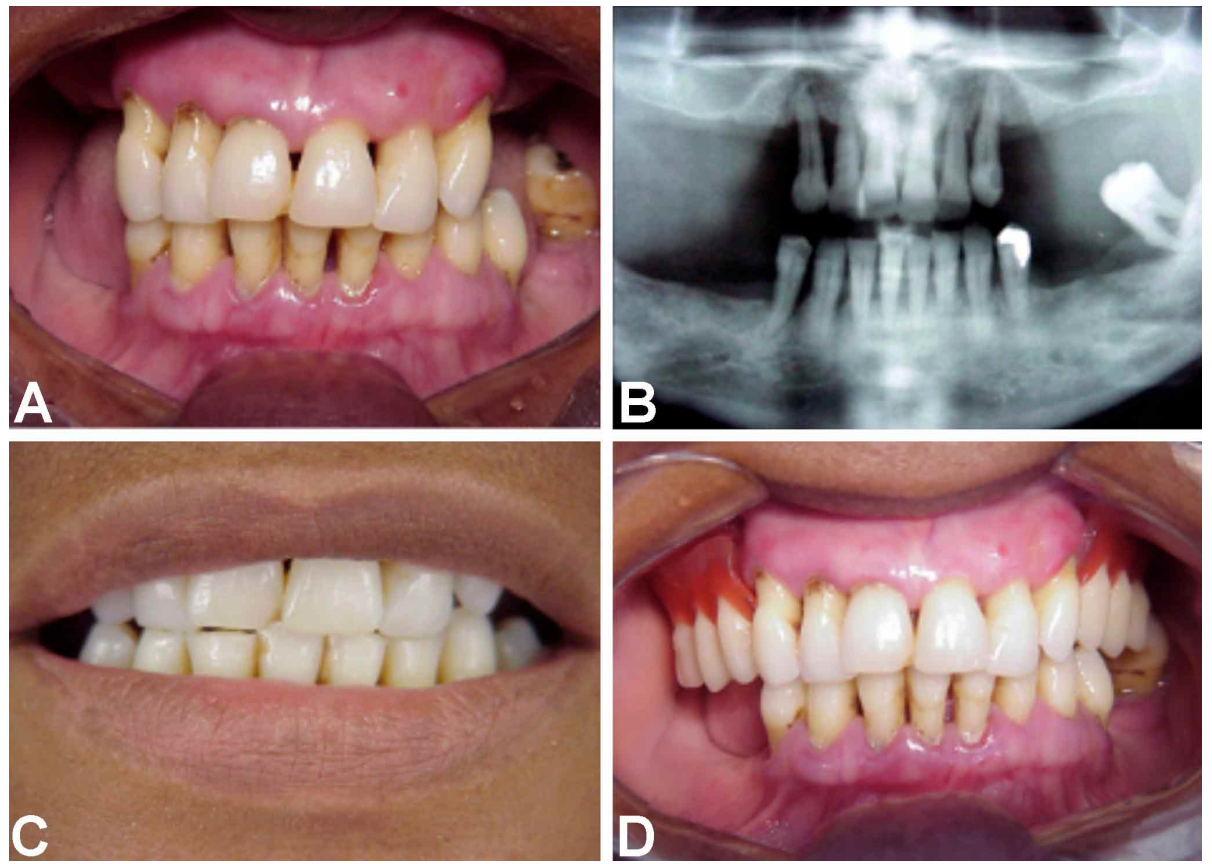

Fig. 1. A. Initial case report; B Panoramic radiograph showing great loss of bone support; C. Smile showing position and alignment of upper anterior teeth; D. Functional fitting of posterior teeth mounted in wax.

\section{CASE REPORT}

A 53-year-old female patient attended the dental clinic for prosthetic rehabilitation in the upper arch. Clinical and radiographic examinations revealed that the patient had six anterior teeth that were periodontally compromised with great loss of bone support, which contraindicated their maintenance in the dental arch (Figs. 1A, B).

The upper anterior teeth were well positioned in the arch and she reported the wish that the future denture would keep the same smile, without transition between natural and artificial, thus preserving the esthetic individuality (Fig. 1C). 
PEREIRA, E. S. B. M.; ACCETTURI, F.; ELEUTÉRIO, R. G.; BUCHAIM, D. V.; BUCHAIM, R. L. \& CLEMENTE-NAPIMOGA, J. T. Reproduction of esthetic individuality in upper immediate complete denture. Int. J. Odontostomat., 14(4):648-652, 2020.
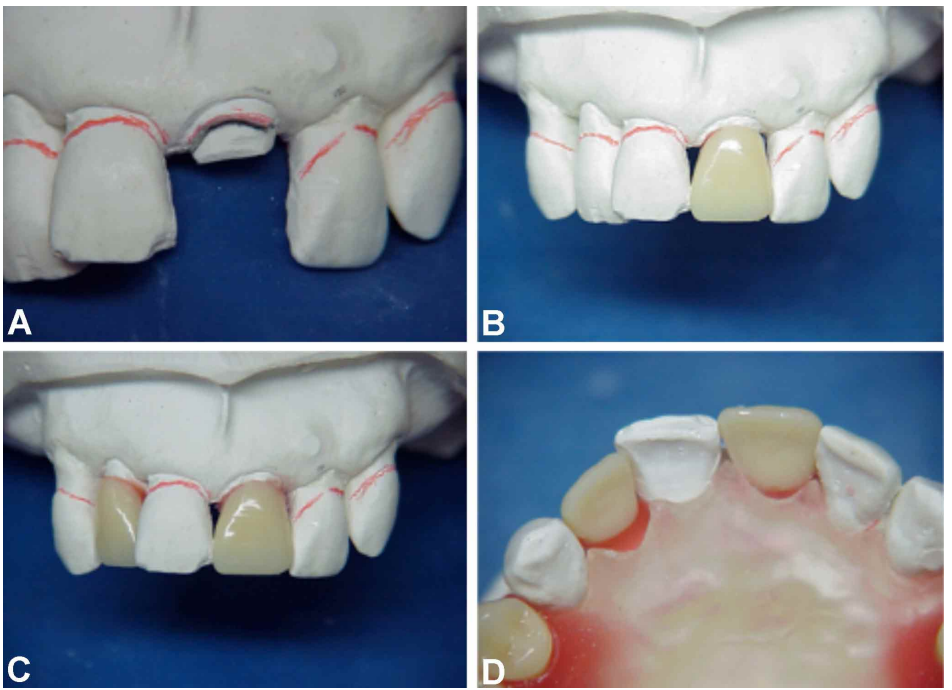

Fig. 2. A. Demarcation of the lines of cervical regions and grinding of the left upper central incisor (tooth 21) in the dental cast (buccal view); B. Assembly of the first left upper central incisor (tooth 21), maintaining the same position as the natural tooth in the dental arch in the dental cast; C. Assembly of upper right lateral incisor (tooth 12) taking the adjacent teeth as reference (buccal view); D. Assembly of upper right lateral incisor (tooth 12) taking the adjacent teeth as reference (palatal view).

The patient also expressed her desire not to be missing her teeth due to esthetics and social life. Treatment with immediate complete denture in the upper arch was proposed, so that she would not be edentulous for any period. Also, to make the immediate denture, the artificial teeth were mounted respecting the same positioning of natural teeth, preserving the patient's natural esthetics. After impression and intermaxillary recordings, functional fitting of teeth at the posterior region of the dental arch was initially performed (Fig. 1D).

Following, surgery was performed on the dental cast for removal of teeth that would be extracted, followed by assembly of the remaining teeth for subsequent application of acrylic.
Firstly, the lines of the cervical regions of anterior teeth were delimited on the functional dental cast, to allow correct and appropriate selection of artificial teeth, whose crowns would be mounted following the same position and arrangement of the natural teeth (Figs. 2A, B).

Grinding was initiated on the dental cast by the upper left central incisor (tooth 21), with assembly of artificial tooth, maintaining the same position as the natural tooth in the dental arch (Fig. 2(C) and (D).

To maintain the naturality and esthetic individuality of the patient, the other artificial teeth were alternately mounted in the dental cast, taking the position of adjacent teeth as reference, thus remaining the same arrangement as the natural teeth in the dental arch (Figs. 3A-C).

After assembly of all anterior teeth, they were joined to the try-in base, followed by waxing and carving. After placement of acrylic, when the denture was ready for placement, surgery was performed for removal of anterior teeth. Extractions, due to the accentuated bone loss that led to the indication of extraction, were performed without trauma, with predominance of root rotation movements of uniradicular teeth (which did not present apical curvatures) and consequently preservation of the alveolar ridge.

In the same session, the denture was placed in the patient's mouth, restoring the same smile, i.e. maintaining her natural appearance and esthetic individuality (Figs. 4A-D).

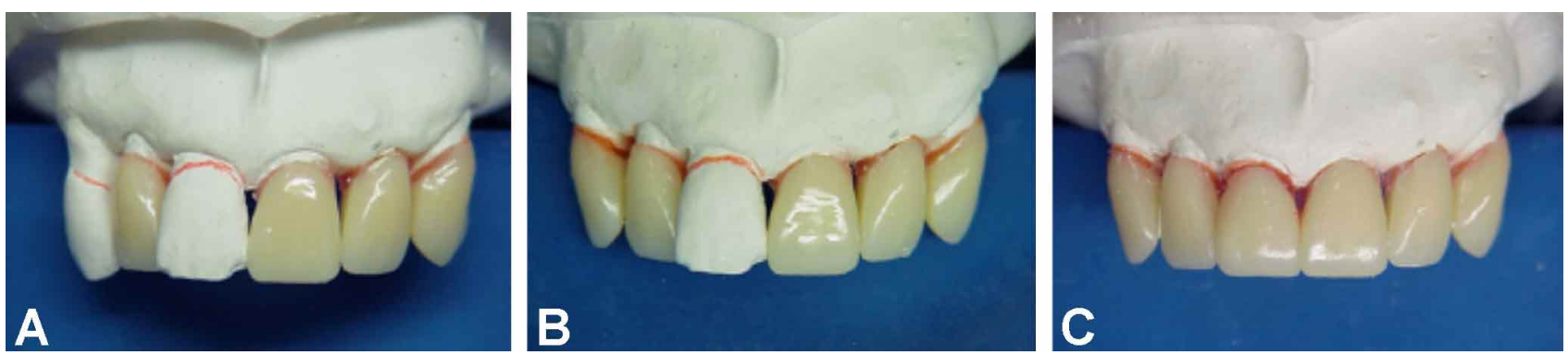

Fig. 3. A. Sequence of assembly of other teeth, alternately, respecting the same positioning and alignment of natural teeth (tooth 22); B. Sequence of assembly of the other teeth, alternately, respecting the same positioning and alignment of natural teeth (tooth 13); C. Sequence of assembly of the other teeth, alternately, respecting the same positioning and alignment of natural teeth (tooth 11). 
PEREIRA, E. S. B. M.; ACCETTURI, F.; ELEUTÉRIO, R. G.; BUCHAIM, D. V.; BUCHAIM, R. L. \& CLEMENTE-NAPIMOGA, J. T. Reproduction of esthetic individuality in uppe immediate complete denture. Int. J. Odontostomat., 14(4):648-652, 2020.
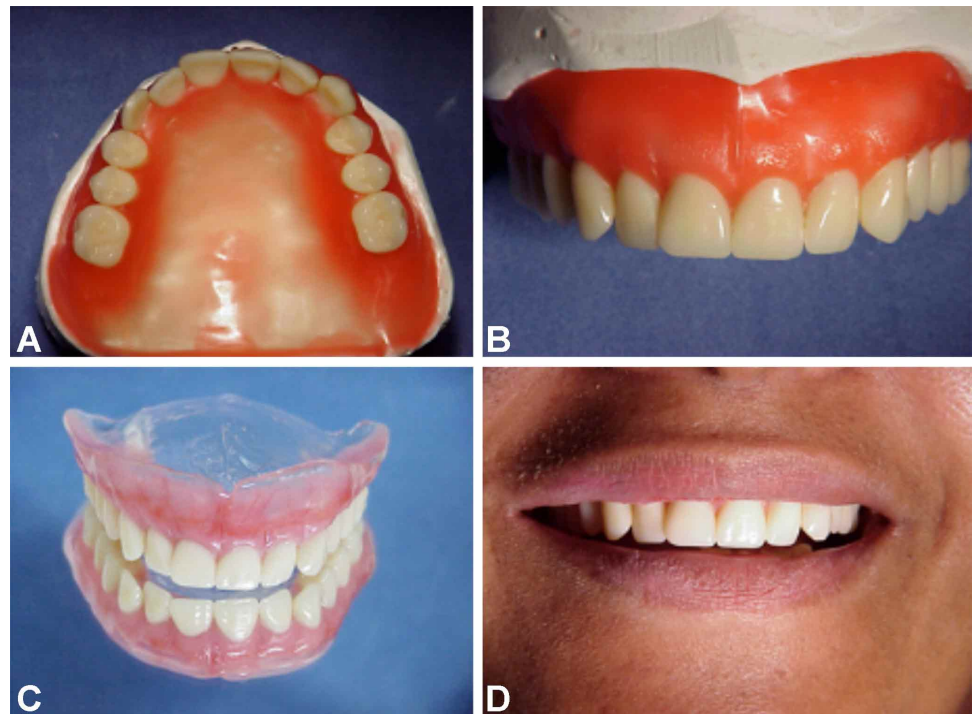

Fig. 4. A. Joining of try-in base to previously mounted anterior teeth; B. Finished waxing and carving of the complete denture (occlusal view); C. Immediate complete denture in acrylic; D. Placement of complete denture in the patient's mouth, evidencing reproduction of the patient's natural smile.

\section{DISCUSSION}

Loss of teeth has a negative influence on essential oral functions (Sharka et al., 2019). Immediate denture is a viable and important rehabilitation method to reestablish the patient's self-esteem, comfort, esthetics and function, and should be well planned and fabricated to achieve the best results (Goiato et al., 2014). Total tooth loss was not only reflected in patient's social behaviour and self-image, but it had a complex and multifaceted impact on satisfaction from complete dentures (Papadaki \& Anastassiadou, 2012).

In prosthodontics and oral rehabilitation, correct reconstruction of the dental anatomy provides greater masticatory efficacy, being a constant search of dental professionals (Buchaim et al., 2014). Additionally, the esthetics in complete dentures involves several factors that, in combination, provide harmony with the face (de Castro Jr. et al., 2000). All factors in combination lead to good esthetics: tooth quality, size, shade, arrangement, alignment, position, artificial gum color, occlusion, vertical dimension and any other resources that may promote the most natural and harmonious appearance as possible. Despite all these resources to achieve denture individualization and the desired esthetics, the patient's opinion is paramount. The concept of esthetics is subjective and individual. Investigators in the field of oral rehabilitation have long been searching to make dentures as similar as possible to the natural dentition (Freitas et al., 2012). For the development of prosthodontics as a science, the physical characteristics of each patient and the pleasant smile are the main references for selection and assembly of artificial teeth. It should also be considered that prosthodontics can be considered an art; as such, it is not adaptable to strict regulations. Whenever possible, the clinician should avoid the symmetry of dental positions, individualizing the denture to each type of patient and oral cavity (McCord \& Grant, 2000; Batista et al., 2000; Pereira et al., 2019).

Thus, the fabrication of individualized dentures for each patient is fundamental for a successful rehabilitative treatment. With the improvement of artificial teeth and the frequent search for reproduction as close to nature as possible, professional skill is often necessary to achieve a harmonious composition of teeth that may be accepted by the patient, who is also searching for esthetics.

In the making of the immediate total denture, the silicone rubber index technique can be used (Dukes et al., 1983), as well as the technique presented in this case report in which the assembly was performed alternately with reference to the neighboring natural teeth that provided an aesthetic smile to the patient.

As limitations of this clinical case, we can consider the non-use of modern oral scanning techniques (Canullo et al., 2018; Venezia et al., 2019), justified by the higher cost mainly in the purchase of equipment that does not match the economic situation of many countries around the world, as well as dental professionals. Regardless of the method used, the clinical and functional results were satisfactory, low cost and affordable, enabling health promotion especially in the elderly population who are more likely to have previous dental loss.

CONCLUSION. The physical characteristics present in each patient and the satisfactory and harmonious smile are paramount for references of selection and assembly of artificial teeth, and also for treatment success. As shown in this case report, the correct observation of the criteria for indication of a customized assembly of artificial teeth allows achieving a denture more similar to the natural dentition, thus maintaining the esthetic individuality of the patient. 
ACKNOWLEDGMENTS. The authors thank Gisele da Silva Dalben, expert in scientific English, for manuscript editing.

PEREIRA, E. S. B. M.; ACCETTURI, F.; ELEUTÉRIO, R. G.; BUCHAIM, D. V.; BUCHAIM, R. L. \& CLEMENTENAPIMOGA, J. T. Reproducción de la individualidad estética en prótesis completa inmediata superior. Int. J. Odontostomat., 14(4):648-652, 2020.

RESUMEN: La prostodoncia, en general, tiene como objetivo rehabilitar la función masticatoria del paciente, así como el sistema estomatognático, manteniendo sus características faciales individuales. La dentadura postiza completa removible se coloca inmediatamente después de la extracción de los dientes naturales y permite la adaptación del paciente del estado dentado a la dentadura, hasta que se coloque la dentadura definitiva. Cuando se fabrica una dentadura postiza completa inmediata, la estética juega un papel fundamental $y$, por lo tanto, el ensamblaje de dientes artificiales se puede realizar manteniendo la misma posición, alineación y disposición de los dientes anteriores restantes, proporcionando un aspecto natural y estético a la dentadura, por lo tanto, la transición desde el estado dentado hasta el estado desdentado es menos notable. Este artículo informa el caso de una paciente que necesitó rehabilitación oral con una dentadura postiza completa superior inmediata y presentó una estética de sonrisa favorable de los dientes anteriores, lo que permitió preservar la alineación, la posición y la disposición de los dientes naturales durante el ensamblaje de los dientes artificiales, manteniendo y preservando la individualidad estética y la armonización facial, satisfaciendo los deseos y expectativas del paciente.

PALABRAS CLAVE: estético; inmediato; dientes artificiales; prótesis total.

\section{REFERENCES}

Afshari, F. S.; Hallas, M. B. \& Knoernschild, K. L. An alternative approach in fabrication of fixed complete dentures using a duplicate denture. J. Prosthodont., 21(7):569-72, 2012.

Bastos, F. B. \& Rodrigues, C. R. T. Prótese total imediata com recuperação da curva de Spee. Braz. J. Surg. Clin. Res., 9(3):116, 2015.

Batista, M. A. C.; Guerra, V. V. A. S.; Fonseca, D. A. \& Mesquita, A. E. O. Estética em prótese total. Rev. Bras. Protes. Clin. Lab., 5:81-6, 2000.

Buchaim, R. L.; Andreo, J. C.; Rodrigues, A. C.; Gonçalves, J. B. O.; Daré, L. R.; Rosa Júnior, G. M.; Buchaim, D. V. \& de Oliveira, J. A. Multidisciplinary approach in the teaching of dental sculpture and anatomy. Int. J. Morphol., 32(2):399-403, 2014.

Canullo, L.; Di Domenico, A.; Marinotti, F.; Menini, M. \& Pesce, P. Soft tissue contour impression with analogic or digital work flow: a case report. Int. J. Environ. Res. Public Health, 15(12):2623, 2018.
Caputi, S.; Murmura, G.; Ricci, L.; Varvara, G. \& Sinjari, B. Immediate denture fabrication: a clinical report. Ann. Stomatol. (Roma), 4(34):273-7, 2013

de Castro Jr., V.; Hvanov, Z. V. \& Frigerio, M. L. M. A. Avaliação estética da montagem dos seis dentes superiores anteriores em prótese total. Pesqui. Odontol. Bras., 14(2):177-82, 2000.

Dukes, B. S.; Fields Jr., H.; Morris, J. C. \& Jewell, A. A comparative study of changes in vertical dimension of occlusion using different investing mediums. J. Prosthet. Dent., 49(4):568-71, 1983.

Fang, J. H.; An, X.; Jeong, S. M. \& Choi, B. H. Digital immediate denture: A clinical report. J. Prosthet. Dent., 119(5):698-701, 2018.

Freitas, M. B.; Pacheco, G. K. \& Zaze, C. A. Seleção de dentes artificiais em próteses odontológicas. Rev. Odontol. Araçatuba, 32(2):70-4, 2012.

Goiato, M. C.; Santos, D. M.; Medeiros, R. A. \& Sonego, M. V. Técnicas de confecção de prótese total imediata mucossuportada. Rev. Odontol. Araçatuba, 35(1):67-72, 2014.

McCord, J. F. \& Grant, A. A. Registration: stage III--selection of teeth. Br. Dent. J., 188(12):660-6, 2000.

Meleti, V. R.; Pinelli, L. A. P.; Pelizaro, D. V. \& Gentil, M. Prótese total imediata: uma solução estética e funcional. Robrac, 11(82):50-3, 2002.

Neumeier, T. T. \& Neumeier, H. Digital immediate dentures treatment: A clinical report of two patients. J. Prosthet. Dent., 116(3):314-9, 2016.

Papadaki, E. \& Anastassiadou, V. Elderly complete denture wearers: a social approach to tooth loss. Gerodontology, 29(2):e721-7, 2012.

Pereira, E. S. B. M.; Accetturi, F.; Eleutério, R. G.; Buchaim, D. V.; Buchaim, R. L. \& Clemente-Napimoga, J. T. Reverse cast metallic core based on the original prosthetic crown. Case Rep. Dent., 2019:6936573, 2019.

Santos, J. C. A.; Silva, J. D. \& Haddad, M. A. Reabilitação com prótese total imediata - relato de caso clínico. Rev. Odontol. Araçatuba, 36(2):24-8, 2015.

Sharka, R.; Abed, H. \& Hector, H. Oral health-related quality of life and satisfaction of edentulous patients using conventional complete dentures and implant-retained overdentures: An umbrella systematic review. Gerodontology, 36(3):195-204, 2019.

Tadi, D. P.; Atluri, A. D.; Kadiayla, D. R. P. \& Suraneni, S. Maxillary immediate denture: a case report. Int. J. App. Basic Med. Res., 3(2):186-9, 2013

Torcato, B. L.; Pellizzer, P. E.; Goiato, M. C. \& Falcon-Antenucci, M. R. Prótese total imediata: relato de caso clínico. Rev. Odontol. Araçatuba, 33(2):66-9, 2012.

Trentin, L. M. T.; Reginato, V. F.; Maroli, A.; Borges, M. T. R.; Spazzin, A. O. \& Bacchi, A. Determinação da dimensão vertical de oclusão em prótese total: revisão de literatura e relato de caso clínico. J. Oral. Investig., 5(1):50-60, 2016.

Venezia, P. \& D'Amato, S. Digital immediate denture: a paradigm shift. Spectr. Dialogue, 16(2):12-8, 2017.

Venezia, P.; Torsello, F.; Santomauro, V.; Dibello, V. \& Cavalcanti, R. Full digital workflow for the treatment of an edentulous patient with guided surgery, immediate loading and 3D-printed hybrid prosthesis: the BARI technique 2.0. A Case Report. Int. J. Environ. Res. Public Health, 16(24):5160, 2019.

Corresponding author:

Eliana de Souza Bastos Mazuqueli Pereira

School of Dentistry, University of Marilia (UNIMAR)

Marília 17525-902

BRAZIL

Email: elianabastosmsn@hotmail.com

Received: 27-04-2020

Accepted: 24-06-2020 